\title{
TOWARDS E-LEARNING IN BASIC SCHOOLS DURING COVID-19: INSIGHTS FROM GHANAIAN TEACHERS
}

\author{
Naa Kai Amanor-Mfoafo ${ }^{1 i}$, \\ Kwamina Kurefi Edonu², \\ Olivia Akrofi ${ }^{3}$, \\ Ebenezer Nortei Dowuona ${ }^{4}$ \\ ${ }^{1}$ Noyam Publishers, \\ Accra, Ghana \\ 2University of Mines and Technology, \\ Tarkwa, Ghana \\ ${ }^{3}$ Kwame Nkrumah University of Science and \\ Technology Primary School, \\ Kumasi, Ghana \\ ${ }^{4}$ University of Professional Studies, \\ Accra, Ghana
}

\begin{abstract}
:
In the wake of the current closure of schools in Ghana, basic schools have been tasked to deliver teaching and learning using e-learning. This study seeks to explore the readiness of teachers in Ghanaian basic schools to undertake e-learning. Using an online questionnaire, data was collected from 108 teachers in both private and public basic schools in Ghana. A factor analysis was conducted to identify the challenges that influenced the ability of basic school teachers to teach using e-learning. The study findings indicated that a majority of the teacher participants preferred face-to-face teaching as compared to online teaching. The study recommends that basic schools adopt a blended approach to teaching where teachers can combine both face-to-face methods with e-learning methods. The study contributes to discussions on the transition from conventional teaching methods to E-learning methods in educational institutions across Ghana.
\end{abstract}

Keywords: e-learning, basic school teachers and learners

\section{Introduction}

The closure of basic schools worldwide due to COVID-19 has necessitated a shift from the conventional face-to-face teaching methods to the use of remote methods. With an

i Correspondence: email naakaiam@noyam.org 
end to the pandemic not in sight, most educational institutions globally have adapted virtual learning methods to enable teaching and learning to continue whilst learners remain home. These new developments in teaching and learning require developing countries to follow the example of developed countries who had made advances in elearning usage before COVID-19. Challenges such as lack of ICT knowledge and poor internet access are barriers hindering the adaption of e-learning in developing countries (Aung \& Khaing, 2015; Asibey et al., 2017; Amanor-Mfoafo et al., 2020). To curb the spread of the pandemic Ghanaian students nationwide have remained home since the closure of schools in March 2020 except for final-year junior high, senior high, and university students who were allowed to return to school in July 2020 to conduct their exit examinations (MyJoyOnline, 2020). Owusu-Fordjour et al., 2020 mention that most Ghanaian tertiary institutions completed the 2020 academic year using Learning Management Systems(LMS) for teaching and learning. Also, some basic schools in the country made attempts to adopt e-learning for teaching and learning whiles learners remained home (Amanor-Mfoafo et al., 2020). The Ministry of Education (MoE) together with the Ghana Education Service (GES) also provided a distance and online learning platform to support learning from home for basic and senior high school students. This provides a daily broadcast of digital content on the new Ghana Learning Television (GLTV) to support e-learning during COVID-19 (Graphic Online, 2020).

In August 2020, after various consultations with major stakeholders, the Ghana Education Service postponed the 2019/2020 academic year to January 2021 as announced in the $16^{\text {th }}$ presidential address to the nation on COVID-19 (Communications Bureau, 2020). As of $28^{\text {th }}$ August, the COVID-19 statistics in Ghana were as follows: the number of active cases: 1059; recovered cases: 42,963; deaths; 276. However, with the drastic reduction in the number of active cases basic schools remain close with the next academic year to resume in January 2021. It was however indicated that measures would be put in place to ensure that nothing is lost from the previous year. This requires that primary school teachers utilize online teaching methods for the next few months leading to the reopening of schools. With these new developments in the educational sector, it would be imperative for teachers to adopt e-learning practices to support teaching and learning even when schools re-open. In this study, we explore the preparedness of Ghanaian basic school teachers to integrate e-learning into teaching and learning. ${ }^{\text {ii }}$ The study would also expose some challenges that may affect the preparedness of basic teaches to using elearning.

\section{Literature Review}

\subsection{E-Learning}

Many related terms such as online learning, virtual learning, web-based learning etc have been used interchangeably with e-learning (Mishra \& Panda, 2007). Likewise, e-learning

\footnotetext{
ii Basic schools in Ghana as used in the context of this study refers to schools offering basic education from nursery to junior high school (MOE, 2019).
} 
has been studied for decades by researchers from various disciplines. Branch \& Dousay (2015) mention that the effectiveness of any e-learning platform hinges on a careful instructional design and planning, using a systematic model for design and development. Alajmi (2010), mentions that the use of e-learning necessitates teachers to embrace a new approach to teaching for a successful implementation. The most important consideration in the adoption of e-learning platforms by institutions should be the ability of both instructors and learners to efficiently utilize the functionalities of the systems. According to Koomson (2020) institutions in some developing countries more often than not adopt learning management systems without first considering their ease of use. Moreover, Elearning programs for institutions should be well monitored at local and national levels. In line with this, the Ghanaian Ministry of Education introduced the Center for National Distance Learning and Open Schooling (CENDLOS) to monitor open and distance learning programmes across tertiary and pre-tertiary institutions in Ghana (Tanye, 2017). With these provisions made, questions on the preparedness of basic school teachers to utilise online learning platforms have not been fully answered.

Many models on e-learning preparedness have been used in various studies globally. Examples of such models include the Chapnick's Model (2000); Borotis and Poulymenakou's model (2004); Bakry's STOPE model (2007); Li-An Ho's model (2009); Chai Lee et al's Model (2009) amongst others. Each of the mentioned models provides a set of factors that can be used to measure e-learning readiness. Technological, Financial, and Psychological factors are predominant in all the models. These models seem appropriate for analysing e-learning preparedness in business organizations and higher educational institutions. However, in this study, the researchers take a queue from the predominant factors to measure e-learning readiness in basic schools focusing on teachers as major stakeholders of the e-learning process.

\subsection{Teacher Preparedness for E-learning}

Studies on e-learning preparedness of schools globally indicate that developed countries depict a high level of preparedness as compared to developing countries (Iddrissu et al., 2020). It is well evident that many studies have been carried out on the preparedness of tertiary institutions to integrate e-learning in teaching (Asibey et al., 2017; Ansong et al., 2017; Bervell \& Umar, 2018). A study conducted in Secondary schools in Kenya showed a poor readiness of schools to utilize virtual learning with instructors having less training on how to integrate technology usage with traditional modes of teaching and learning (Wilson et al. 2015; Ngatia, 2015). On the Ghanaian front, the Ghana Education Service (GES), through its new educational policy, emphasizes the importance of a technologybased pedagogy in the school curriculum.

To analyse e-learning preparedness, So \& Swatman (2005), used factor analysis to determine the factors influencing the e-learning readiness of teachers in Hong Kong. The factors discovered included: Learners' Preparedness; Teachers' Preparedness; IT Infrastructure; Management Support; School Culture and Preference to meet face-to-face. Similarly using a multistakeholder approach, Ansong et al. (2017) also used factor analysis to discover and explore the technological, organizational, and environmental 
determinants of e-learning adoption in the University of Ghana. Their findings indicated some disparities in the adoption factors for the three e-learning stakeholders (students, instructors, and administrators).

On related studies e-learning in Ghana during COVID-19, Aboagye (2020) examined the challenges faced by 63 tutors sampled from various Colleges of Education in Ghana as they transition from face-to-face (conventional) to online learning. The study concluded that if tutors adopt a blended approach comprising of delivery via face-to-face methods while assessment and access to learning materials should be done online to ensure an effective transition. Gyampo et al. (2020) hypothesised that only a handful of the tutors can confidently teach online while the majority of them would have preferred additional training. Their study examined tutor perception on personal and institutional preparedness for online teaching and learning among tutors of colleges of education in Ghana. Owusu-Fordjour et al also surveyed 250 students in tertiary and second cycle institutions in Ghana. Results from their study indicated that e-learning platforms rolled out in Ghana posed challenges to many students. Their study recommended that students and teachers alike be introduced to e-learning platforms to enable effective usage for teaching and learning.

Similarly, Iddrisu et al. (2020) explored senior high school teachers' preparedness for the integration of online learning in Social Studies teaching and learning amongst 972 students and 84 Social Studies students from 12 secondary schools in the Northern Region of Ghana. It was discovered that all schools had ICT laboratories and were connected to electric power for online learning. However, most classrooms were not connected to electricity to support virtual learning. Schools were not sufficiently equipped with ICT tools and lacked local ICT in education policy guidelines to guide Elearning during CoVID-19.

Henaku (2020) mentions that both social media and online learning platforms were used teaching and learning at the tertiary and pre-tertiary levels though they faced challenges such as the high cost of internet bundles, challenges with devices etc.

These studies reveal that much work on e-learning in Ghana focuses on tertiary and second cycle institutions as compared to basic schools. This study, therefore, seeks to focus on e-learning in Basic school.

\section{Material and Methods}

A survey research design was used to collect responses from both teachers in basic schools across different regions in Ghana. Using a purposive sampling approach data was gathered from a random sample of 108 teachers. This involved teachers from primary 1-6 and Junior High School (JHS) in both public and private institutions. Questionnaires were administered to respondents using google forms and the printed format. The questionnaire comprised of 15 questions on the respondent's demographic data and preparedness for e-learning. The data was collected between June and August 2020. 91 valid responses were recorded. These responses are presented and discussed in the 
section below. Descriptive statistics, one-way analysis of variance (ANOVA), post hoc tests, and Factor Analysis were applied to analyse the data using SPSS version 20.

\section{Results and Discussion}

\subsection{Demographic Characteristics of Respondents}

Table 1 below shows the result of the demographic analysis of the 91 teacher respondents.

Table 1: Demographic Analysis of Respondents

\begin{tabular}{|c|c|c|}
\hline Items & Frequency & Percent \\
\hline \multicolumn{3}{|c|}{ Respondents' Gender } \\
\hline Male & 43 & 47.3 \\
\hline Female & 48 & 52.7 \\
\hline \multicolumn{3}{|l|}{ Respondents' Age } \\
\hline Below 30yrs & 26 & 28.6 \\
\hline $30-40 y r s$ & 49 & 53.8 \\
\hline $41-50 y r s$ & 8 & 8.8 \\
\hline $51-60 y r s$ & 8 & 8.8 \\
\hline \multicolumn{3}{|c|}{ Respondents' highest educational level } \\
\hline Senior High & 4 & 4.4 \\
\hline Diploma & 30 & 33.0 \\
\hline Bachelor's Degree & 52 & 57.1 \\
\hline Master's Degree & 5 & 5.5 \\
\hline \multicolumn{3}{|c|}{ Type of School Respondents' teach } \\
\hline Private & 39 & 42.9 \\
\hline Public & 52 & 57.1 \\
\hline
\end{tabular}

Source: Field Data, 2020.

As presented in Table 1 above, female respondents formed the majority of the total number of respondents $(52.7 \%)$. On age distribution, $28.6 \%$ of the respondents were aged below 30 years, 53.8\% were aged between $30-40$ years, $8.8 \%$ were aged between $41-50$ years, and $8.8 \%$ were aged between $51-60$ years. $57.1 \%$ happened to be degree holders. Similarly, $57.1 \%$ of the respondents taught in public basic schools while $42.9 \%$ taught in private basic schools.

As seen in Figure 1 below, the majority of the people teacher respondents taught in schools located in the Ashanti and Western regions of Ghana. Results also displayed in Figure 2 indicated that (76.92\%) respondents teach in the primary school's whiles $23.08 \%$ of the respondents teach in the Junior High Schools (JHS). 


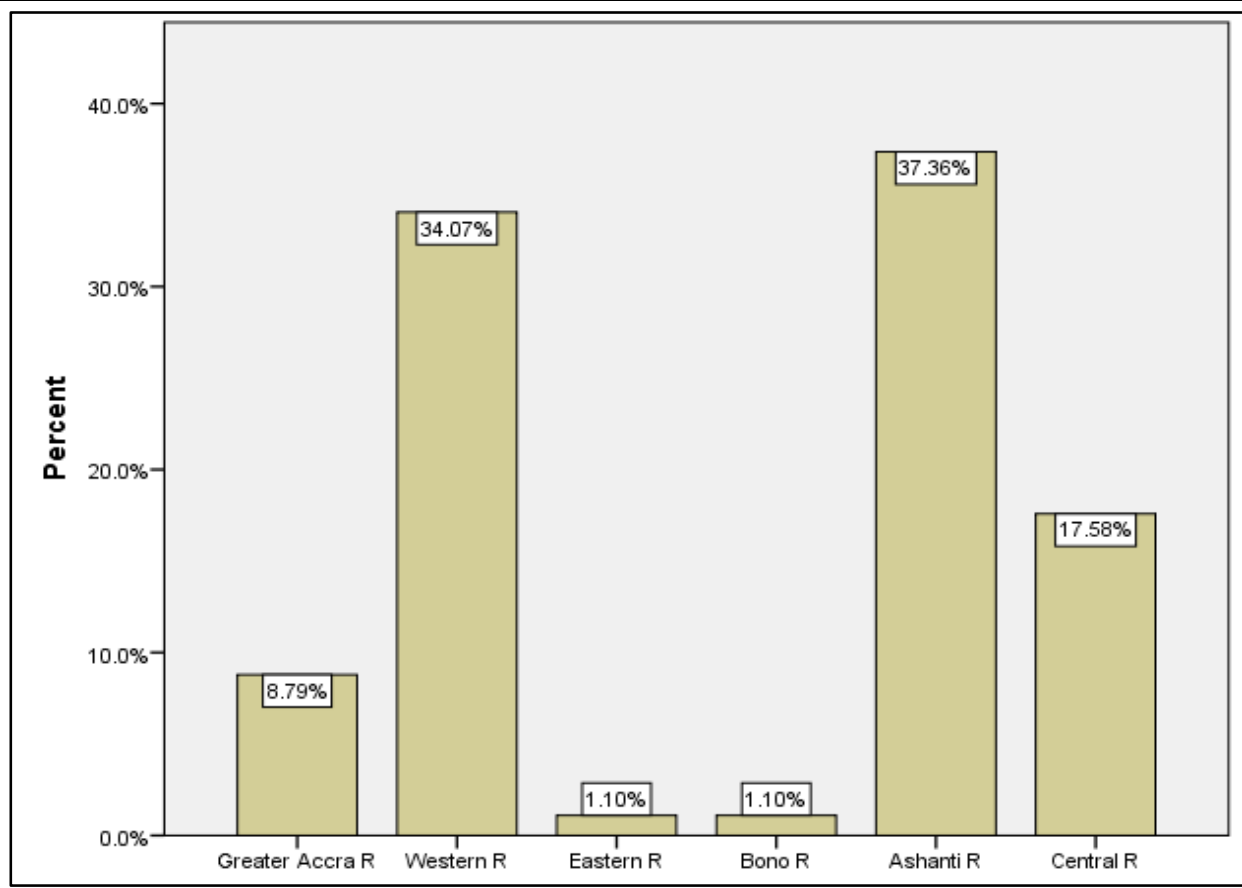

Figure 1: Location of Respondents' School

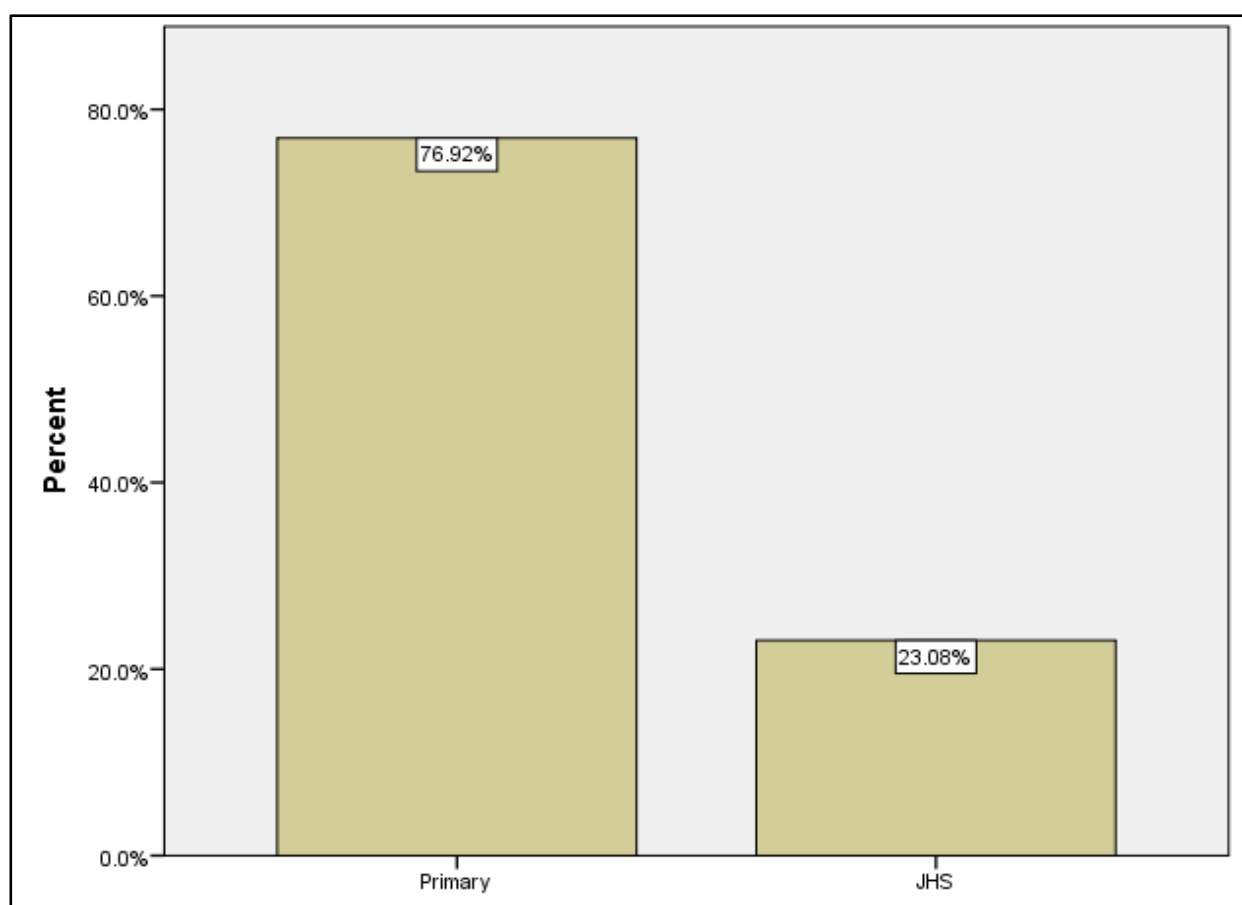

Figure 2: Class Respondents Teach

\subsection{Reliability Analysis}

Creswell, 2012 posits that reliability and validity analysis are crucial to conducting a study that is void of false perdition. It measures the credibility of the individual instruments identified to measure the research objectives as well as the research findings in a study. Therefore, the reliability of the instrument was conducted using Cronbach's alpha coefficient. Table 2 below, presents the results of the reliability analysis. 
Table 2: E-Learning Readiness of Ghanaian Teachers

\begin{tabular}{|c|c|c|}
\hline Items & CA if Item Deleted & CA \\
\hline 1. I know about e-learning & .659 & \\
\hline 2. The parents of my students support the use of e-learning at home & 692 & \\
\hline 3. My students have enough IT skills to use e-learning technologies & .682 & \\
\hline 4. I think e-learning is helpful to improve teaching and learning & .709 & \\
\hline 5. I am ready for integrating e-learning in my teaching & .690 & .711 \\
\hline 6. Access to the internet is not a problem for me & .679 & \\
\hline 7. The IT infrastructure in my school can support e-learning & .652 & \\
\hline $\begin{array}{l}\text { 8. My school can afford the budget of using e-learning in Teaching \& } \\
\text { Learning }\end{array}$ & .680 & \\
\hline 9. I prefer face-to-face lessons with my students & 751 & \\
\hline 10. My principal / senior management supports the use of e-lea & .671 & \\
\hline
\end{tabular}

Source: Field Data, 2020.

The instruments identified to conduct research are considered reliable if its reliability analysis, specifically the Cronbach's alpha coefficient is at least 0.7 (Hair et al, 2012). The Cronbach's alpha (CA) coefficient of .711 as indicated in Table 2 suggested that effective, credible, and reliable items have been identified to measure the extent to which Ghanaian teachers are prepared to support their students in e-learning and the challenges involved. The results also suggested that almost all the individual instruments are relevant to the study and therefore none of them should be eliminated in conducting the main analysis since the deletion of any will reduce the Cronbach's alpha coefficient.

\section{Main Findings}

Descriptive statistics (frequency and mode) were employed to analyze the data collected about the e-learning readiness of Ghanaian teachers. Table 3 below shows the results of the analysis.

Table 3: Perceived e-learning Readiness of Ghanaian Teachers during COVID-19

\begin{tabular}{|l|c|c|c|c|}
\hline \multirow{2}{*}{ Items } & $\mathbf{S D}$ & $\mathbf{D}$ & $\mathbf{A}$ & $\mathbf{S A}$ \\
& $\mathbf{F} \%$ & $\mathbf{F} \%$ & $\mathbf{F} \%$ & $\mathbf{F} \%$ \\
\hline \multirow{2}{*}{ I know about e-learning } & 9 & 9 & 34 & 39 \\
\hline \multirow{2}{*}{ The parents of my students support the use of e-learning at home } & 9.9 & 9.9 & 37.4 & 42.9 \\
\hline \multirow{2}{*}{ My students have enough IT skills to use e-learning technologies } & 20 & 28 & 34 & 9 \\
\hline \multirow{2}{*}{ I think e-learning is helpful to improve teaching and learning } & 22 & 30.8 & 37.4 & 9.9 \\
\hline \multirow{2}{*}{ I am ready for integrating e-learning in my teaching } & 22 & 33 & 24 & 12 \\
\cline { 2 - 5 } & 24.2 & 36.3 & 26.4 & 13.2 \\
\hline \multirow{2}{*}{ Access to the internet is not a problem for me } & 7 & 17 & 35 & 32 \\
\cline { 2 - 5 } & 7.7 & 18.7 & 38.5 & 35.2 \\
\hline \multirow{2}{*}{ The IT infrastructure in my school can support e-learning } & 11 & 7 & 40 & 33 \\
\cline { 2 - 5 } & 12.1 & 7.7 & 44 & 36.3 \\
\cline { 2 - 5 } & 24 & 17 & 32 & 18 \\
\hline
\end{tabular}




\begin{tabular}{|l|c|c|c|c|}
\hline \hline \multirow{2}{*}{ My school can afford the budget of using e-learning in Teaching \& Learning } & 38 & 20 & 22 & 11 \\
\cline { 2 - 5 } & 41.8 & 22 & 24.2 & 12.1 \\
\hline \multirow{2}{*}{ I prefer face-to-face lessons with my student } & 5 & 9 & 27 & 50 \\
\hline & 5.5 & 9.9 & 29.7 & 54.9 \\
\hline \multirow{2}{*}{ My principal / senior management supports the use of e-learning } & 11 & 16 & 45 & 19 \\
\cline { 2 - 5 } & 12.1 & 17.6 & 49.5 & 20.9 \\
\hline
\end{tabular}

Source: Field Data 2020.

The results in Table 3 above show that about $19.8 \%$ of the respondents do not know about e-learning, while $80.3 \%$ of the respondents agreed that they know about e-learning. $52.8 \%$ of the respondents against $47.3 \%$ confirmed that parents of their students do not support the use of e-learning at home. Again, about $39.6 \%$ of the respondents acknowledged that their students have enough IT skills to use-e-learning technologies with $60.5 \%$ admitting that their students do not have the requisite IT skills to use e-learning technologies. Concerning the respondent's opinion on whether e-learning is helpful to improve teaching and learning, $73.7 \%$ of the respondents agreed that e-learning helps to improve teaching and learning. However, $26.4 \%$ of the respondents thought otherwise. Again, $80.3 \%$ of the respondents indicated that they are ready to integrate e-learning in their teaching, but $19.8 \%$ of the respondents indicated that they are not prepared to do so. The results further demonstrated that $55 \%$ of the respondents do not have any problem concerning access to the internet. However, $45.1 \%$ of the respondents admitted that internet access is a major problem for them. $50.6 \%$ of the respondents indicated that the IT infrastructure in the school can support e-learning, and $49.5 \%$ of the respondents also admitted that the IT infrastructure in their school cannot support e-learning in their school. $63.8 \%$ of the respondents disclosed that their school cannot afford the budget of using e-learning in teaching \& learning. The rest of the respondents (36.3\%) however indicated that the school can afford the budget of using e-learning in teaching \& learning. Conversely, $84.6 \%$ of the respondents against $15.4 \%$ point out that they prefer face-toface lessons with their students to e-learning. Finally, $70.4 \%$ of the respondents showed that their principals/ senior management support the use of e-learning.

\subsection{Factors Influencing the E-learning Readiness of Ghanaian Teachers}

A four-level scale was constructed in the questionnaire to identify the preparedness of Ghanaian basic school teachers for E-learning. 10 variables were used to conduct Principal Component Factor Analysis of e-learning readiness of Ghanaian teachers in SPSS version 20. Varimax rotation with the Kaiser Normalization method was used. Individual loading of 0.55 or greater was used in factor designation. Four factors with Eigenvalues equal to or greater than one were extracted. Interpretive labels were suggested for each of these factors according to their characters as seen in Table 5 below. 
Table 5: Factors Extracted by SPSS with Interpretative Labels

\begin{tabular}{|l|c|c|c|c|}
\hline Items & Factor 1 & Factor 2 & Factor 3 & Factor 4 \\
\hline $\begin{array}{l}\text { 5. I am ready for integrating e-learning in my } \\
\text { teaching }\end{array}$ & .887 & & & \\
\hline 1. I know about e-learning & .744 & & & \\
\hline $\begin{array}{l}\text { 4. I think e-learning is helpful to improve teaching } \\
\text { and learning }\end{array}$ & .732 & & & \\
\hline $\begin{array}{l}\text { 2. The parents of my students support the use of e- } \\
\text { learning at home }\end{array}$ & & .870 & & \\
\hline $\begin{array}{l}\text { 10. My principal / senior management supports the } \\
\text { use of e-learning }\end{array}$ & & .661 & & \\
\hline $\begin{array}{l}\text { 3. My students have enough IT skills to use e- } \\
\text { learning technologies }\end{array}$ & & .580 & & \\
\hline $\begin{array}{l}\text { 7. The IT infrastructure in my school can support e- } \\
\text { learning }\end{array}$ & & & .874 & .836 \\
\hline 6. Access to the internet is not a problem for me & & & .605 & \\
\hline $\begin{array}{l}\text { 8. My school can afford the budget of using e- } \\
\text { learning in Teaching \&amp; Learning }\end{array}$ & & & & .937 \\
\hline 9. I prefer face-to-face lessons with my students & & & \\
\hline $\begin{array}{l}\text { Extraction method: Principal Component Analysis. } \\
\text { Rotation method: Varimax with Kaiser Normalization. }\end{array}$ & & & \\
\hline
\end{tabular}

\section{Factor 1: Teacher Preparedness}

- I am ready for integrating e-learning in my teaching

- I know about e-learning

- I think e-learning is helpful to improve teaching and learning

Factor 2: Institutional and Parental Preparedness

- The parents of my students support the use of e-learning at home

- My principal / senior management supports the use of e-learning

- My students have enough IT skills to use e-learning technologies

Factor 3: Infrastructural Preparedness

- The IT infrastructure in my school can support e-learning

- Access to the internet is not a problem for me

- My school can afford the budget of using e-learning in Teaching \&amp; Learning

Factor 4: Teaching Preference

- I prefer face-to-face lessons with my students

Extraction method: Principal Component Analysis.

Rotation method: Varimax with Kaiser Normalization.

\section{Discussion}

This section discusses the results of the analysed data. The data analysed sampled four factors influencing the preparedness of Ghanaian basic school teachers in adopting the use of e-learning. These include Teacher Preparedness, Institutional and Parental Preparedness, Infrastructural Preparedness and Teaching Preference. Similar factors we identified by So \& Swatman (2005) in their study on the E-learning Readiness of Hong Kong teachers. 
On infrastructural, institutional and parental preparedness, the results suggested that $63.8 \%$ of the respondents disclosed that their schools could not afford the budget of using e-learning in teaching and learning. The rest of the respondents (36.3\%) however indicated that the school can afford the budget of using e-learning in teaching and learning. These findings agree with Iddrisu et al. (2020) who found out that most schools were not sufficiently equipped with ICT tools and lacked local ICT in education policy guidelines to guide e-learning. Aung \& Khaing (2015) also mention challenges such as poor network infrastructure, lack of ICT knowledge, weakness of content development, etc. as some of the many challenges to implementing e-learning in developing countries. $52.08 \%$ of the teacher respondents indicated that parents of the wards are unable to support their children with E-learning. Amanor-Mfoafo et al. (2020) are however of the view that the socio-economic status of parents is a key determinant on parents' preparedness to assist their wards with e-learning.

On teacher preparedness and preference, it was evident that in Table 3 above that about $19.8 \%$ of the respondents did not know much about e-learning, while $80.3 \%$ of the respondents agreed that they knew about e-learning. Despite their knowledge of elearning, $84.6 \%$ of the respondents against $15.4 \%$ point out that they prefer face-to-face lessons with their students to e-learning. Bervell and Umar (2018) agree that the emergence of many e-learning solutions enhances teaching and learning, however, the benefit of physical presence provided by face-to-face teaching is still a preferred medium for most instructors.

Edumadze et al. (2014) also agree that many lecturers in Ghanaian tertiary institutions are unable to fully utilize e-learning resources for teaching because they lack requisite technological skills. Furthermore, Gyampo et al. (2020) are of the view that a handful of the tutors can confidently teach online while the majority of them would have preferred additional training. These findings add up to the ongoing debate on the teacher's readiness to utilise online teaching technologies in Ghana. Another angle to the debate has been the adoption of a blended approach to the transition to online teaching as mentioned by Aboagye (2020); Bervell and Umar (2020). According to Siemens et al., (2015), what constitutes a blended approach to e-learning is still debatable. However, Garrison \& Kanuka (2004) explain that a simple explanation of the blended approach is the combination of both physical presence and online aspects of teaching and learning. In the context of basic schools, the blended mode may require teachers to teach learners face-to-face and deliver learning material, course assignments and assessments using an online system.

Considering the level of preparedness of basic school teachers to fully teach online, the researchers argue that it would be difficult for most basic schools in Ghana to fully transition to online learning within the next couple of years. This assertion is based on barriers identified from the study findings namely lack of technical skills required by teachers, lack of e-learning infrastructure in basic schools and inadequate parental support with e-learning. 


\section{Recommendations}

The study recommends that basic schools in Ghana adopt a blended approach to elearning delivery before transitioning to a fully online mode of teaching. Hence, Basic schools should provide teachers with continuous e-learning training sessions to aid them in becoming more conversant with online teaching methods. As the majority of the study respondents were from the Ashanti and Western regions of Ghana, it would be prudent for future studies to have more respondents from across the other regions of Ghana. Also, future studies could focus on case studies comparing the use of e-learning in public and private basics in Ghana. Lastly, the researchers recommend that the basic school curriculum should be structured to incorporate both online and conventional (face to face) in teaching and learning across the country.

\section{Conclusion}

With the use of e-learning being referred to as the new normal, this study identified some challenges that hindered the preparedness of basic school teachers in utilizing e-learning teaching method. Based on the findings the researchers justify the need for basic schools to adopt a blended approach comprising of both online and face-to-face modes of teaching delivery.

\section{Acknowledgments}

The authors wish to acknowledge all the Basic teachers who willingly offered to take part in the study.

\section{About the Author(s)}

Naa Kai Amanor-Mfoafo currently works an Administrative Manager at Noyam Publishers (An Academic Research Publisher) in Accra, Ghana. She has research interests in Technology-Mediated Teaching and Learning.

Kwamina Kurefi Edonu is the Head of the Audio-Visual Unit, University of Mines and Technology, Tarkwa, Ghana. He has research interests in Education and Design Innovation.

Olivia Akrofi is a Chief Teacher at Kwame Nkrumah University of Science and Technology (KNUST) Primary School, Kumasi, Ghana. She has research interests in Guidance and Counselling Education.

Ebenezer Nortei Dowuona recently completed his Bachelor of Arts Degree in Business Administration from the University of Professional Studies, Accra, Ghana. He has research interests in Business Management and Information Technology. 


\section{References}

Aboagye E. (2020). Transitioning from Face-to-Face to Online Instruction in the COVID19 Era: Challenges of Tutors at Colleges of Education in Ghana Social Education Research 2(1): 9-19. doi: 10.37256/ser.212021545.

Alajmi M. (2010). Faculty Members' Readiness for E-Learning in the College of Basic Education in Kuwait. PhD Thesis, University of North Texas.

Amanor-Mfoafo N. K., Akrofi O., Edonu K. K., Dowuona E. N. (2020). Investigating the E-Learning Readiness of Ghanaian Parents During COVID-19. European Journal of Education Studies 7 (10): 39-56. doi: 10.46827/ejes.v7i10.3275

Ansong E., Boateng S. L., Boateng R. (2017). Determinants of E-Learning Adoption in Universities: Evidence from a Developing Country. Journal of Educational Technology Systems 46(1): 30-60. doi:10.1177/0047239516671520

Asibey B. O., Agyemang S., Dankwah B. A. (2017). The Internet Use for Health Information Seeking among Ghanaian University Students: A Cross-Sectional Study. International Journal of Telemedicine and Applications. 1-9. doi: $10.1155 / 2017 / 1756473$

Aung T., Khaing S. (2015). Challenges of Implementing e-Learning in Developing Countries: A Review. Advances in Intelligent Systems and Computing, 388.doi: 10.1007/978-3-319-23207-2_41

Bakry S. H., Khalid A., Abdulmohsen A. (2007). STOPE-based Approach for e-Readiness Assessment Case Studies: Department of Electrical Engineering, King Saud University, Riyad, Saudi Arabia. International Journal of Network Management, 18: 65-75.

Bervell B., Umar I. N. (2018). Blended learning or face-to-face? Does Tutor anxiety prevent the adoption of Learning Management Systems for distance education in Ghana?, Open Learning: The Journal of Open, Distance and e-Learning, 159-177. doi: 10.1080/02680513.2018.1548964

Borotis S., Poulymenakou A. (2004). E-Learning Readiness Components: Key Issues to Consider Before Adopting e-Learning Interventions. In J. Nall \& R. Robson(Eds.), Proceedings of E-Learn 2004--World Conference on E-Learning in Corporate, Government, Healthcare, and Higher Education : 1622-1629.

Branch R. M., Dousay T. A. (2015). Survey of instructional design models (5th ed.). Association for Educational Communications \& Technology. https://aect.org/survey of instructional design.php.

Chai L. G, Poh Y. N. (2009). E-learning in Malaysia: Success Factors in Implementing Elearning Program, Curtin University of Technology. International Journal of Teaching and Learning in Higher Education, 20(2): 237- 246.

Chapnick S. (2000). Are you ready for e-learning? Learning Circuits: ASTD's Online Magazine All About ELearning, https://nurhadiw.files.wordpress.com/2010/08/are you ready for elearning.pdf Accessed 12 August 2020. 
Creswell J. W. (2012). Research Design: Qualitative, Quantitative and Mixed Methods Approaches, 3rd edition. ed. SAGE Publications, Inc, Thousand Oaks.

Edumadze J. K., Ossei-Anto T. A., Edumadze G., Tamakloe W. K., Asamoah E., Ernest Boadi E. (2014). Evaluating the Awareness and Perceptions of Lecturers in using E-Learning Tools for Teaching in University of Cape Coast. International Journal of Computing Academic Research 3(1) :1-11.

Garrison D. R., Kanuka H. (2004). Blended learning: Uncovering its transformative potential in higher education. The Internet and Higher Education, 7(2): 95-105.

GraphicOnline (2020). Ministry of Education implements virtual learning - To engage students at home. https://www.graphic.com.gh/news/general-news/ghana-newsministryof-education-implements-virtual-learning-to-engage-students-athome.html. Accessed 7 June, 2020.

Hair J. F., Sarstedt M., Ringle C. M., Mena J. A. (2012). An assessment of the use of partial least squares structural equation modeling in marketing research. J. Acad. Mark. Sci. 40: 414-433.

Henaku E. A. (2020). COVID-19: Online Learning Experience of College Students: The Case of Ghana. International Journal of Multidisciplinary Sciences and Advanced Technology, 1 (2):54-62.

Iddrisu B., Samson R. O., Mueni O. (2020). Preparedness of Ghanaian Senior High School Instructors for Application of Online Learning in Social Studies Instruction amid the Covid-19 Pandemic. Social Education Research 2(1): 56-64. doi: 10.37256/ser.212021554

Li-An H. (2009). The Antecedents of e-Learning Outcome: An Examination of System Quality, Technology Readiness and Learning Behaviour. Department of Educational Technology, Tamkang University, Taiwan. Adolescence, 44(175): 581599.

Mishra S., Panda S. (2007). Development and Factor Analysis of an Instrument to measure Students Attitude Towards E-learning, Asian Journal of Distance Education $5(1): 27-33$.

MyJoyOnline (2020). Full text of Akufo-Addo's 10th address to the Nation on Coronavirus Crisis. https://www.myjoyonline.com/news/national/full-text-of-akufoaddos10th-address-to-the-nation-on-coronavirus-crisis/ Accessed 2 June, 2020

MyJoyOnline (2020). Update No 16: Measures Taken To Combat Spread Of Coronavirus. http://www.presidency.gov.gh/index.php/briefing-room/speeches/1674-updateno-16-measures-taken-to-combat-spread-of-coronavirus Accessed 3 September, 2020.

Ngatia P. K. (2015). Preparedness of public secondary schools on the use of information communication technology in teaching and learning in Mukurweini, Nyeri County-Kenya. Master's Thesis: Kenyatta University, Kenya.

Owusu-Fordjour C., Koomson C. K., Hanson D. (2020). The Impact of Covid-19 on learning -the perspective of the Ghanaian student. European Journal of Education Studies, 7(3) :88 - 101. doi: 10.5281/zenodo.3753586 
Siemens G, Gašević D, Dawson S. (2015). Preparing for the digital university: A review of the history and current state of distance, blended and online learning. Retrieved from

http://citeseerx.ist.psu.edu/viewdoc/download?doi=10.1.1.728.1692\&rep=rep1\&ty pe=pdf

So K. K., Swatman P. M. (2005). e-Learning Readiness in the Classroom: Hong Kong primary teachers. University of South Australia.

Tanye H. A. (2017). Quality E-learning in distance learning: Benefits and Implications for national E-learning policy in Ghana. International Journal of Multicultural and Multireligious Understanding, 4(3): 1-11. doi: 10.18415/ijmmu.v4i3.73

Wilson S, Lydiah N, \& Pachomius W. (2015). School's preparedness in information communication technology integration in teaching and learning in public secondary schools. A case of Kieni east sub-county Nyeri County, Kenya. IOSR Journal of Humanities and Social Science 20(2), 90-99. 
Naa Kai Amanor-Mfoafo, Kwamina Kurefi Edonu, Olivia Akrofi, Ebenezer Nortei Dowuona TOWARDS E-LEARNING IN BASIC SCHOOLS DURING COVID-19: INSIGHTS FROM GHANAIAN TEACHERS

Creative Commons licensing terms

Authors will retain the copyright of their published articles agreeing that a Creative Commons Attribution 4.0 International License (CC BY 4.0) terms will be applied to their work. Under the terms of this license, no permission is required from the author(s) or publisher for members of the community to copy, distribute, transmit or adapt the article content, providing a proper, prominent and unambiguous attribution to the authors in a manner that makes clear that the materials are being reused under permission of a Creative Commons License. Views, opinions and conclusions expressed in this research article are views, opinions and conclusions of the author(s). Open Access Publishing Group and European Journal of Open Education andE-learning Studies shall not be responsible or answerable for any loss, damage or liability caused in relation to/arising out of conflict of interests, copyright violations and inappropriate or inaccurate use of any kind content related or integrated on the research work. All the published works are meeting the Open Access Publishing requirements and can be freely accessed, shared, modified, distributed and used in educational, commercial and non-commercial purposes under a Creative Commons Attribution 4.0 International License (CC BY 4.0). 